\title{
Growth of Bacillus stearothermophilus on glycerol in chemostat culture: expression of an unusual phenotype
}

\author{
Ronald M. BuRKe and David W. TemPest* \\ Department of Molecular Biology and Biotechnology, University of Sheffield, Sheffield S10 2TN, UK
}

(Received 1 March 1990; accepted 10 April 1990)

\begin{abstract}
Bacillus stearothermophilus grew readily on glycerol in carbon-limited chemostat culture and expressed a high carbon conversion efficiency. However, the strain of organism used (probably B. stearothermophilus var. nondiastaticus) proved particularly sensitive to glycerol, both respiration and growth being severely impeded by any surfeit of this compound. Sensitivity was found to correlate with an exceptionally high level of expression of glycerol kinase |activities of more than $80 \mu \mathrm{mol} \mathrm{min}^{-1}(\mathrm{mg} \text { protein })^{-1}$ were manifest in crude cell-free extracts], coupled with low activities of methylglyoxal synthase and of glyoxylase (enzymes of the methylglyoxal bypass). It is proposed that metabolic dysfunction results from an uncontrolled gross accumulation of glycerol phosphate (and early products of its metabolism) within the cells, coupled with depletion of the intracellular phosphate pool.
\end{abstract}

\section{Introduction}

Most strains of Bacillus stearothermophilus will grow on a wide range of carbon substrates including sugars, polyols and organic acids. Our strain possesses this property but unexpectedly displayed a remarkable sensitivity to glycerol, even when this compound was present in only a slight excess of the growth requirement. This was manifest in batch culture by a protracted lag period (generally of more than $24 \mathrm{~h}$ ), and in chemostat culture by extreme difficulty in establishing steady-state growth of organisms in glycerol-sufficient environments. Moreover, under these latter conditions, chemostat cultures generally could be stably maintained only when glycerol was present in a barely detectable excess in the extracellular fluids. Indeed, even glycerol-limited cultures were sensitive to large step changes in dilution rate, and though steady-state conditions could readily be attained at dilution rates of up to $1.0 \mathrm{~h}^{-1}$, any sudden addition of excess glycerol to these cultures caused respiration to cease and the culture to be washed from the fermenter. These observations clearly must have a rational physiological basis, and thus prompted a closer study of the physiology of this organism when growing on glycerol in chemostat culture. As detailed later, growth on this substrate appeared to provoke a massive overproduction of glycerol kinase, particularly under glycerol-limiting conditions, where almost $40 \%$ of the total protein content of the cell could be accounted for by this enzyme alone. Also the presence of this enzyme at a high activity could well effect a metabolic dysfunction when excess glycerol is present that would account for the observed sensitivity of these organisms to glycerol. Evidence is presented in support of this proposition.

\section{Methods}

Organism and culture conditions. The organism used in this study was a near-prototrophic strain of Bacillus stearothermophilus that, apart from the carbon and energy source, required only biotin as an organic supplement. In all its characteristics it appeared to be identical with the strain B. stearothermophilus var. non-diastaticus (Epstein \& Grossowicz, 1969).

Organisms were routinely grown in chemostats (LH Fermentation, 500 series, 1 litre growth vessel providing $700 \mathrm{ml}$ working volume) in defined simple salts media (Evans et al., 1970) at $55^{\circ} \mathrm{C}$ and at pH 7.0. Glycerol was provided as the carbon and energy source and, in general, all non-limiting nutrients were present in at least a threefold excess. The complete medium (including glycerol) was made in 20 litre batches and sterilized by autoclaving at $121^{\circ} \mathrm{C}$ for $30 \mathrm{~min}$. The temperature and $\mathrm{pH}$ of the cultures were controlled automatically and foaming was suppressed by the addition of a silicone-based antifoaming agent when required, as sensed by a foam probe. Dissolved oxygen was monitored using a polarographic oxygen electrode (Ingold) and its concentration maintained above $50 \%$ saturation by varying the stirrer speed.

Analyses. $\mathrm{O}_{2}$ consumption and $\mathrm{CO}_{2}$ production by the cultures were determined by passing the effluent gas through an $\mathrm{O}_{2}$ analyser (Taylor Servomex, type $\mathrm{OA}$ 272) and a $\mathrm{CO}_{2}$ analyser (Servomex IR gas analyser, PA 404). Respiration rates were then calculated as specified by Pennock \& Tempest (1988), bacterial dry weights being assessed by the procedure of Herbert et al. (1971).

Production of overflow metabolites was detected, and quantified, by 
using an HPLC apparatus (LKB) fitted with an Aminex HPX 87H organic acid analysis column (Bio-Rad), a 2142 refractive index detector (LKB) and an SP4270 integrator (Spectra Physics). The column temperature was $55^{\circ} \mathrm{C}$ and the eluent was $5 \mathrm{~mm}-\mathrm{H}_{2} \mathrm{SO}_{4}$. Glycerol was determined enzymically following the procedure of Wieland (1974).

Enzyme activities. In the preparation of cell-free extracts, organisms from steady-state chemostat cultures were centrifuged $(5000 \mathrm{~g}$ for $10 \mathrm{~min}$ ), washed with $50 \mathrm{mM}$-phosphate buffer $(\mathrm{pH} \mathrm{7.0)}$ and sonified six times for $30 \mathrm{~s}$ at $75 \mathrm{~W}$ in a B-12 Sonifier (Branson) with intermittent $30 \mathrm{~s}$ periods of cooling in an ice-water mixture. They were then centrifuged at $20000 \mathrm{~g}$ for $10 \mathrm{~min}$ and the supernatant fraction used for the determination of enzyme activities. Glycerol kinase was assayed according to the method of Bergmeyer (1974), and methylglyoxal synthase and glyoxylase I and II according to the methods of Cooper \& Anderson (1970). Glycerol dehydrogenase activity was sought using the procedure of Streekstra et al. (1987) but seemingly was absent. Protein was determined using the method of Lowry, as modified by Peterson (1977). All enzyme activities are expressed as $\mu \mathrm{mol} \mathrm{min}^{-1}$ (mg protein $)^{-1}$

Purification of glycerol kinase. Cell extracts were centrifuged at $161000 \mathrm{~g}$ for $3 \mathrm{~h}$ in order to sediment ribosomes, and the supernatant fraction was loaded onto columns containing either AMP-Sepharose 4B or Procion blue MX-3G Sepharose CL6B equilibrated with $100 \mathrm{mM}$ phosphate buffer, $\mathrm{pH} 7.5$ (bed volume of $20 \mathrm{ml}$ ). Procion blue was coupled to Sepharose CL6B according to the method of Baird et al. (1976). Columns were eluted as follows. (a) Columns containing AMPSepharose 4B were eluted with $100 \mathrm{~mm}$-phosphate buffer $(\mathrm{pH} 7.5$ ) followed by a linear gradient of 0-1.0 mM-ATP in $100 \mathrm{mM}$-phosphate buffer ( $\mathrm{pH}$ 7.5). (b) Columns containing dye conjugate were eluted with $100 \mathrm{~mm}$-phosphate buffer (pH 7.5) followed by the same buffer containing $1 \mathrm{M}-\mathrm{KCl}$.

Column eluates were monitored for absorption at $280 \mathrm{~nm}$ and fractions containing protein were assayed immediately for glycerol kinase activity and then treated with trichloroacetic acid $(5 \%$, w/v, end concentration) for analysis by PAGE. It was assumed that this concentration of acid would irreversibly inactivate protease. SDSPAGE was done according to the method of Laemmli (1970). Native gels were run under identical conditions in the absence of SDS.

Reagents. All reagents used were of the best analytical grade commercially available.

\section{Results and Discussion}

\section{Glycerol-limited cultures}

B. stearothermophilus will grow readily in glycerol-limited chemostat culture $\left(55^{\circ} \mathrm{C}, \mathrm{pH} 7 \cdot 0\right)$ at dilution rates up to $1 \cdot 0 \mathrm{~h}^{-1}$ (Table 1$)$. The yield value with respect to glycerol is high, attaining a maximum value at a dilution rate $(D)$ of $0.6 \mathrm{~h}^{-1}$ of $54.5 \mathrm{~g} \mathrm{~mol}^{-1}$ (i.e. a conversion efficiency of substrate carbon to cell carbon of $0.75 \mathrm{~g} \mathrm{~g}^{-1}$ ). However, during the course of this experiment it became clear that the culture was extraordinarily sensitive to glycerol. It would tolerate only small step increases in dilution rate: ones of more than about $0 \cdot 2 \mathrm{~h}^{-1}$, at low dilution rates, or $0 \cdot 3 \mathrm{~h}^{-1}$, at the higher dilution rates, invariably caused the culture to wash out. Similarly, a sudden addition of
Table 1. Influence of the dilution rate on the rates of glycerol and $\mathrm{O}_{2}$ consumption, and of $\mathrm{CO}_{2}$ production, expressed by a glycerol-limited chemostat culture of

$B$. stearothermophilus when growing in a simple salts medium at $55^{\circ} \mathrm{C}$ and at $\mathrm{pH} 7.0$

The values of metabolic rates are means of measurements made over at least $4 \mathrm{~d}$.

\begin{tabular}{ccccc}
\hline \hline $\begin{array}{c}\text { Dilution } \\
\text { rate }\left(\mathrm{h}^{-1}\right)\end{array}$ & $\begin{array}{c}\text { Glycerol } \\
\text { uptake } \\
{\left[\mathrm{mmol} \mathrm{h}^{-1}\right.}\end{array}$ & $\begin{array}{c}\mathrm{O}_{2} \\
\text { uptake } \\
(\mathrm{g} \text { dry wt cells }\end{array}$ & $\begin{array}{c}\mathrm{CO}_{2} \text { output } \\
\text { ond }\end{array}$ & $\begin{array}{c}\text { Carbon } \\
\text { recovery } \\
(\%)\end{array}$ \\
\hline 0.13 & 3.4 & 5.3 & 4.5 & 97 \\
0.21 & 4.7 & 5.3 & 4.4 & 93 \\
0.31 & 6.3 & 7.3 & 6.0 & 100 \\
0.42 & 7.8 & 8.4 & 6.6 & 103 \\
0.61 & 11.6 & 12.4 & 9.5 & 100 \\
0.81 & 16.6 & 15.7 & 13.2 & 94 \\
1.00 & 20.6 & 20.3 & 15.4 & 92 \\
\hline \hline
\end{tabular}

glycerol ( $1 \mathrm{mg} \mathrm{ml}^{-1}$, end concentration) caused respiration to collapse and the culture to be washed from the fermenter.

\section{Glycerol-sufficient cultures}

This obvious sensitivity to excess glycerol made it extremely difficult to establish glycerol-sufficient cultures. Nevertheless, by starting with a low concentration of glycerol (virtually a dual limitation) and gradually increasing it, it was possible to grow $B$. stearothermophilus under conditions of sulphate, phosphate and potassium limitations. Under all such conditions, however, the excess (unused) glycerol concentration had to be maintained at barely detectable levels. These glycerolsufficient cultures utilized glycerol at two to three times the rate of a corresponding glycerol-limited culture (Table 2). The extra glycerol consumed was oxidized mainly to $\mathrm{CO}_{2}$, with the specific rates of $\mathrm{O}_{2}$ consumption and $\mathrm{CO}_{2}$ production being increased proportionately. Again, there was sensitivity to fluctuations in the environment and transient increases in dilution rate and/or glycerol concentration caused the culture to wash out. Clearly either glycerol or some product of glycerol metabolism was toxic to the cells, and this prompted an investigation of the cellular content of enzymes of glycerol metabolism.

\section{Enzymes of glycerol metabolism in glycerol-limited cells}

In some organisms, like Klebsiella aerogenes ( $K$. pneumoniae), the primary enzyme of glycerol metabolism is either the high-affinity glycerol kinase or the low-affinity glycerol dehydrogenase, depending upon whether the culture is, respectively, glycerol-limited or glycerolsufficient (Neijssel et al., 1975). This appeared not to be 
Table 2. Influence of the specific growth limiting nutrient on the metabolic rate of a chemostat culture of

$B$. stearothermophilus growing on glycerol at $55^{\circ} \mathrm{C}$ and at $\mathrm{pH} 7 \cdot 0$

The values of metabolic rates are means of measurements made over at least $4 \mathrm{~d}$.

\begin{tabular}{|c|c|c|c|c|c|}
\hline Limitation & $\begin{array}{l}\text { Dilution } \\
\text { rate }\left(\mathrm{h}^{-1}\right)\end{array}$ & $\begin{array}{l}\text { Glycerol } \\
\text { uptake } \\
{\left[\mathrm{mmol} \mathrm{h}^{-1}\right.}\end{array}$ & $\begin{array}{c}\mathrm{O}_{2} \\
\text { uptake } \\
\text { (g dry wt }\end{array}$ & $\begin{array}{c}\mathrm{CO}_{2} \\
\text { output } \\
\left.\text { celis) })^{-1}\right]\end{array}$ & $\begin{array}{c}\text { Carbon } \\
\text { recovery } \\
(\%)\end{array}$ \\
\hline Sulphate & $0 \cdot 13$ & $6 \cdot 8$ & $11 \cdot 2$ & $8 \cdot 3$ & 68 \\
\hline Phosphate & $\begin{array}{l}0.13 \\
0.24 \\
0.41 \\
0.61 \\
0.76\end{array}$ & $\begin{array}{r}5.5 \\
9.6 \\
20 \cdot 3 \\
21.9 \\
22.4\end{array}$ & $\begin{array}{l}12 \cdot 1 \\
24 \cdot 9 \\
37 \cdot 8 \\
38 \cdot 6 \\
28 \cdot 2\end{array}$ & $\begin{array}{r}9.2 \\
19.0 \\
30.6 \\
28 \cdot 2 \\
22.5\end{array}$ & $\begin{array}{r}89 \\
101 \\
78 \\
82 \\
81\end{array}$ \\
\hline Potassium & $\begin{array}{l}0.11 \\
0.21\end{array}$ & $\begin{array}{r}7 \cdot 7 \\
10.7\end{array}$ & $\begin{array}{l}18 \cdot 7 \\
23 \cdot 0\end{array}$ & $\begin{array}{l}16 \cdot 1 \\
20 \cdot 3\end{array}$ & $\begin{array}{l}90 \\
91\end{array}$ \\
\hline
\end{tabular}

the case with $B$. stearothermophilus which seemingly is unable to synthesize the dehydrogenase. However, glycerol kinase activity was invariably present, and at an astonishingly high level in glycerol-limited cells (Table 3 ). Thus, at a dilution rate of $0.61 \mathrm{~h}^{-1}$ the specific activity of glycerol kinase in cell-free extracts was $82.5 \mu \mathrm{mol}$ $\min ^{-1}$ (mg protein $)^{-1}$, which was more than $75 \%$ of the reported activity of the pure enzyme (Comer et al., 1979)! It seemed highly improbable that this enzyme alone could account for more than three-quarters of all the protein synthesized by the cells, and so purification of the enzyme present in these extracts was undertaken. Unfortunately, despite repeated attempts at affinity column chromatography we were unable to obtain a preparation that was electrophoretically homogeneous. Nevertheless, analysis of extracts by SDS-PAGE (Fig. 1) revealed a major band of protein of apparent molecular mass $56-60 \mathrm{kDa}$ in the region expected for glycerol kinase (molecular mass $58 \mathrm{kDa}$ - see Comer et al., 1979), and the most purified preparations to date had a specific activity of 220 (compared with 116) $\mu \mathrm{mol} \mathrm{min}^{-1}$ (mg protein $)^{-1}$. This still implies that, in organisms growing at a dilution rate of $0.61 \mathrm{~h}^{-1}$, almost $40 \%(\mathrm{w} / \mathrm{w})$ of all the protein synthesized can be accounted for by this enzyme alone (see Table 3).

Interestingly, glycerol kinase activity is much decreased in organisms growing at a dilution rate of $1.0 \mathrm{~h}^{-1}$, where the extracellular glycerol concentration must be close to a cell-saturating level. This suggested that glycerol kinase synthesis might be repressed by excess glycerol, in which case glycerol-sufficient cells should possess substantially lower activities of this enzyme than glycerol-limited cells. Whereas this clearly is the case (Table 4), the activity present in the potassium-limited cell extract, in particular, was not substantially lower than that present in the correspond-

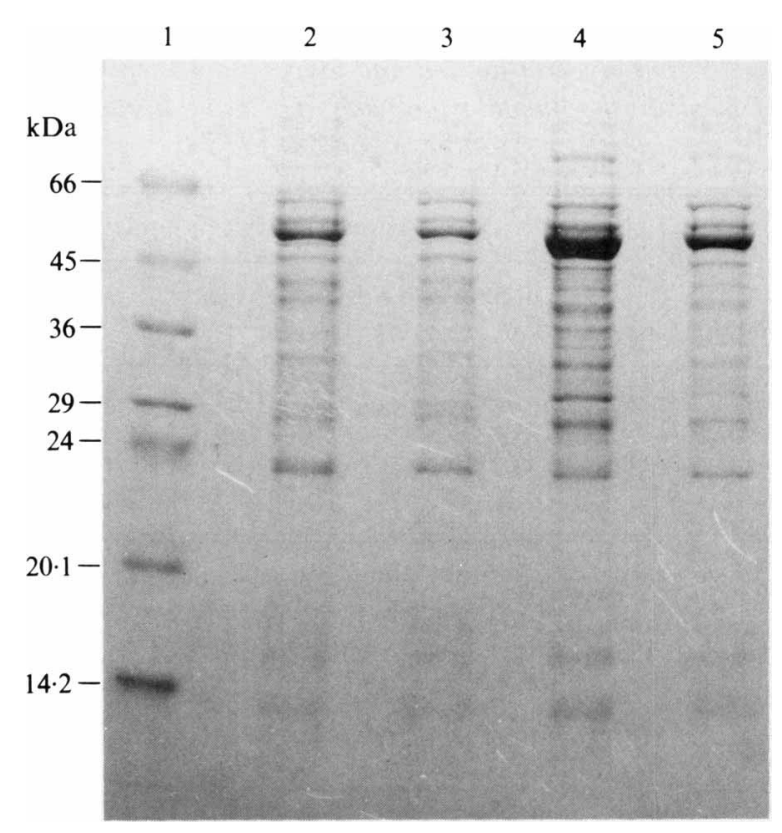

Fig. 1. SDS-PAGE of cell extracts. The tracks are numbered as follows: 1, standard molecular mass markers (bovine serum albumin, $56 \mathrm{kDa}$; egg albumin, $45 \mathrm{kDa}$; glyceraldehyde 3-phosphate dehydrogenase, $36 \mathrm{kDa}$; carbonic anhydrase, $29 \mathrm{kDa}$; trypsinogen, $24 \mathrm{kDa}$; trypsin inhibitor, $20 \cdot 1 \mathrm{kDa} ; \alpha$-lactalbumin, $14.2 \mathrm{kDa}$ ); 2 , crude cell-free extract from a phosphate-limited culture; 3 , supernatant fluid from crude extract of a phosphate-limited culture that had been centrifuged at $45000 \mathrm{~g}$ for $3 \mathrm{~h} ; 4$, crude cell-free extract from a glycerol-limited culture; 5 , supernatant fluid from a glycerol-limited culture that had been centrifuged at $45000 \mathrm{~g}$ for $3 \mathrm{~h}$.

Table 3. Glycerol kinase activity in cell-free extracts from a glycerol-limited chemostat culture of B. stearothermophilus growing at $55^{\circ} \mathrm{C}(\mathrm{pH} 7)$ at different dilution rates

\begin{tabular}{ccc}
\hline $\begin{array}{c}\text { Dilution rate* } \\
\left(\mathrm{h}^{-1}\right)\end{array}$ & $\begin{array}{c}\text { Specific activity } \\
{\left[\mu \mathrm{mol} \mathrm{min}^{-1}(\mathrm{mg} \text { protein })^{-1}\right]}\end{array}$ & $\begin{array}{c}\text { Enzyme content } \\
\text { as a percentage of } \\
\text { total protein } \dagger\end{array}$ \\
\hline $0.13(3)$ & $63.4 \pm 3.2$ & 29 \\
$0.21(4)$ & $47.0 \pm 4.0$ & 21 \\
$0.30(5)$ & $67.2 \pm 5.8$ & 31 \\
$0.42(5)$ & $74.5 \pm 4.6$ & 34 \\
$0.61(3)$ & $82.5 \pm 5.9$ & 38 \\
$0.81(2)$ & $44.6 \pm 1.7$ & 20 \\
$1.00(4)$ & $12.7 \pm 1.2$ & 6 \\
\hline \hline
\end{tabular}

* Figures in parentheses show the number of samples examined.

$\dagger$ Based on a specific activity of $220 \mu \mathrm{mol} \mathrm{min}^{-1}\left(\mathrm{mg}\right.$ protein $\left.{ }^{-1}\right)$ for the pure enzyme.

ing glycerol-limited cell extract. In the above connection, it should be mentioned that the reported glycerol kinase activity of $\boldsymbol{B}$. stearothermophilus grown on glycerol in a rich medium, in batch culture, was relatively low [200 units (g dry cells) $)^{-1}$, or $0.4 \mu \mathrm{mol} \mathrm{min}^{-1}\left(\mathrm{mg} \mathrm{protein}^{-1}\right)$ ] and lower than that of cells grown on glycerol in a simple salts medium (Atkinson et al., 1975; Atkinson \& Comer, 1983).

The sensitivity to glycerol of glycerol-sufficient cells 
Table 4. Activities of some enzymes of glycerol metabolism in cells from glycerol-limited and glycerol-sufficient cultures of $B$. stearothermophilus growing at a fixed dilution rate $\left(0 \cdot 1 h^{-1}\right)$ at $55^{\circ} \mathrm{C}$ and at $\mathrm{pH} 7 \cdot 0$

\begin{tabular}{lccc}
\hline \hline & \multicolumn{3}{c}{ Activity $\left[\mu \mathrm{mol} \mathrm{min}^{-1}(\mathrm{mg} \text { protein })^{-1}\right]$} \\
\cline { 2 - 4 } Limitation* & $\begin{array}{c}\text { Glycerol } \\
\text { kinase }\end{array}$ & $\begin{array}{c}\text { Methylglyoxal } \\
\text { synthase }\end{array}$ & $\begin{array}{c}\text { Glyoxylase } \\
\text { I and II }\end{array}$ \\
\hline Glycerol (3) & $63.4 \pm 3.2$ & $0.26 \pm 0.04$ & $0.20 \pm 0.06$ \\
Potassium (4) & $40.3 \pm 2.9$ & $0.43 \pm 0.09$ & $1.32 \pm 0.06$ \\
Sulphate (8) & $5.0 \pm 0.2$ & $0.43 \pm 0.01$ & $0.50 \pm 0.17$ \\
Phosphate (5) & $8 \cdot 1 \pm 0.7$ & $0.62 \pm 0.12$ & $3.21 \pm 0.03$ \\
\hline \hline
\end{tabular}

* Figures in parentheses show the number of samples examined.

was not uniform but varied with the nature of the growth limitation. Potassium-limited cells were particularly sensitive; it was impossible to grow such cultures at dilution rates greater than $0 \cdot 21 \mathrm{~h}^{-1}$. Sulphate-limited cultures were much less sensitive, and phosphate-limited cultures were even less sensitive to fluctuations in their growth environment and could be readily grown at dilution rates in excess of $0.7 \mathrm{~h}^{-1}$ (Table 2).

The fact that a step increase in the dilution rate from $0 \cdot 1$ to $0 \cdot 2 \mathrm{~h}^{-1}$ with a potassium-limited culture led not only to a collapse of respiration and washout, but to excretion of lactic acid (data not shown) suggested a possible involvement of enzymes of the methylglyoxal bypass. Hence cell extracts were assayed for the relevant enzymes - methylglyoxal synthase, and glyoxylase I and II - which were indeed found to be present (Table 4). Moreover, a careful examination of enzyme levels suggested a possible explanation for the varying sensitivities of the glycerol-sufficient cultures. Thus, not only was the glycerol kinase activity low in phosphate-limited cells, but the methylglyoxal synthase and glyoxylase activities were high. Potassium-limited cells also had a high glyoxylase activity, but the glycerol kinase activity was fivefold that of the phosphate-limited cells. Sulphate-limited cells had the lowest glycerol kinase activity, but also the lowest glyoxylase activity. We would therefore propose that sensitivity to glycerol is a complex function of the activities of a number of enzymes, but primarily that of glycerol kinase. Thus when the glycerol kinase activity is high, glycerol will be rapidly converted to glycerol phosphate which would tend to accumulate intracellularly to high levels and transiently to deplete the ATP pool. The respiratorychain-linked oxidation of glycerol phosphate to dihydroxyacetone phosphate would effectively regenerate the ATP pool, but in doing so at a high rate would deplete the intracellular inorganic phosphate pool. The latter could be overcome by invoking the reactions of the methylglyoxal bypass, which converts dihydroxyacetone phos- phate into lactate and inorganic phosphate. However, any imbalance between the activities of methylglyoxal synthase and glyoxylase would cause an accumulation of methylglyoxal, which is highly toxic to cells. Herein, we suggest, lies the subtlety of the enzymic balance.

Sensitivity towards glycerol, provoked by high levels of glycerol kinase, has been demonstrated previously with both Escherichia coli and $K$. aerogenes. The deleterious effect of an over-consumption of glycerol was elegantly demonstrated with a mutant of $E$. coli that was constitutive for glycerol kinase and lacked feedback control of this enzyme (Zwaig et al., 1970). When exposed to glycerol ( $1 \mathrm{mM}$, end concentration) this organism rapidly lost viability. Similarly, washed cells from a glycerol-limited culture of $K$. aerogenes that presumably had high levels of glycerol kinase activity (see Neijssel et al., 1975) also lost viability rapidly when exposed to similarly low concentrations of glycerol (Postgate \& Hunter, 1964). In this latter case, however, it was found that loss of viability could be circumvented by adding cAMP to the suspension, and hence the phenomenon of so-called 'substrate-accelerated death' could be ascribed, at least in part, to suppression of adenyl cyclase activity (Calcott \& Postgate, 1974). Nevertheless, high levels of specific enzymes such as glycerol kinase clearly create problems of metabolic imbalance that impede cellular proliferation, and it is therefore curious that an otherwise highly versatile wild-type organism like $B$. stearothermophilus should possess this seemingly aberrant phenotype.

We gratefully acknowledge the invaluable help provided by colleagues in the Laboratory of Microbiology, University of Amsterdam, The Netherlands, in carrying out HPLC analyses of some culture supernatant fluids. This work formed part of the Biotechnology Action Programme of the CEC under contract number BAP-0270-UK (Hl).

\section{References}

ATKInson, A. \& COMER, M. J. (1983). Thermostable glycerokinase. US Patent no. $4385120 \mathrm{~A}$.

Atkinson, A., Evans, C. G. T. \& Yeo, R. G. (1975). Behaviour of Bacillus stearothermophilus grown in different media. Journal of Applied Bacteriology 38, 301-304.

Baird, J. K., Sherwood, R. F., CARR, R. J. G. \& Atkinson, A. (1976). Enzyme purification by substrate elution chromatography from procion dye-polysaccharide matrices. FEBS Letters 70, 61-66.

Bergmeyer, H. U. (1974). Methoden der enzymatischen Analyse, 3rd edn, vol. 1, p. 498. Weinheim: Verlag Chemie.

Calcott, P. H. \& Postgate, J. R. (1974). The effects of $\beta$ galactosidase activity and cyclic AMP on lactose accelerated death. Journal of General Microbiology 85, 85-90.

Comer, M. J., Bruton, C. J. \& Atkinson, T. (1979). Purification and properties of glycerolkinase from Bacillus stearothermophilus. Journal of Applied Biochemistry 1, 259-270.

COOPER, R. A. \& ANDERSON, A. (1970). The formation and catabolism of methylglyoxal during glycolysis in Escherichia coli. FEBS Letters 11, 273-276. 
Epstein, I. \& Grossowicz, N. (1969). Prototrophic thermophilic Bacillus: isolation, properties and kinetics of growth. Journal of Bacteriology 99, 414-417.

Evans, C. G. T., Herbert, D. \& Tempest, D. W. (1970). The continuous cultivation of micro-organisms. 2. Construction of a chemostat. Methods in Microbiology 2, 227-327.

Herbert, D., Phipps, P. J. \& Strange, R. E. (1971). Chemical analysis of microbial cells. Methods in Microbiology 5B, 209-344.

LAEMMLI, U. K. (1970). Cleavage of structural proteins during the assembly of the head of bacteriophage T4. Nature, London 227, 680-685.

Neijssel, O. M., Hueting, S., Crabbendam, K. J. \& Tempest, D. W. (1975). Dual pathways of glycerol assimilation in Klebsiella aerogenes NCIB 418. Their regulation and possible functional significance. Archives of Microbiology 104, 83-87.

PENNOCK, J. \& TEMPEST, D. W. (1988). Metabolic and energetic aspects of the growth of Bacillus stearothermophilus in glucose-limited and glucose-sufficient chemostat culture. Archives of Microbiology 150, 452-459.
Peterson, G. L. (1977). A simplification of the protein assay method of Lowry et al. which is more generally applicable. Analytical Biochemistry 83, 346-356.

Postgate, J. R. \& Hunter, J. R. (1964). Accelerated death of Aerobacter aerogenes starved in the presence of growth-limiting substrates. Journal of General Microbiology 34, 459-473.

Streekstra, H., Teixeira de Mattos, M. J., Neijssel, O. M. \& TEMPEST, D. W. (1987). Overflow metabolism during anaerobic growth of Klebsiella aerogenes NCTC 418 on glycerol and dihydroxyacetone in chemostat culture. Archives of Microbiology 147, 268-275.

Wieland, O. (1974). Glycerol: uv methode. In Methoden der enzymatischen Analyse, 3rd edn, vol. 2, pp. 1448-1450. Edited by H. U. Bergmeyer. Weinheim: Verlag Chemie.

ZWAig, N., KistLeR, W. S. \& LIN, E. C. C. (1970). Glycerolkinase, the pacemaker for the dissimilation of glycerol in Escherichia coli. Journal of Bacteriology 102, 753-759. 